\title{
The Matters of Intellectual Property in the Practice of the European Court of Human Rights
}

\author{
Marina Alexandrovna Rozhkova \\ Professor, Department of Civil Law and Department of Intellectual Property Law of the Kutafin Moscow State Law University \\ rozhkova-ma@mail.ru

\section{Dmitry Victorovich Afanasiev}

Teaches civil law and the law of the intellectual property at the Kutafin Moscow State Law University, Sadovaya-Kudrinskaya street, 9, Moscow, 125993, Russia

echr.mail@gmail.com

\section{Doi:10.5901/mjss.2015.v6n3s3p241}

\begin{abstract}
Article 1(1) of Protocol No. 1 to European Convention on Human Rights provides that every person is entitled to peaceful enjoyment of his possessions. Meanwhile, European Court of Human Rights in its processional practice gives rather wide interpretation of "property" category and refers to it not only physical objects, but also, inter alia, company shares, patents, goodwill in business, license to serve alcoholic beverages and other rights or interests, which are being economically significant or bear property nature. As the consequence, intellectual property rights, which, undoubtedly, can not be referred to physical objects, by virtue of high economical significance and property nature fit under the "property" category in accordance with Article 1 of Protocol No. 1. However, the central thesis of the present paper is that not any rights linked to the results of intellectual activity can be considered intellectual property rights, as well as not all the rights linked to intellectual property get protection on the basis of Article 1 of Protocol No. 1 to Convention. The conclusion is that some rights linked to getting legal protection of intellectual activity results can not be considered intellectual property rights, but being at the same time the property rights they fit under protection of Article 1 of Protocol No. 1 to Convention. Other rights linked to realization of creative potential are not considered "property" and can not be protected with help of Article 1 of Protocol No. 1 to Convention, but can get protection in accordance with other provisions of European Convention on Human Rights (for example, of Article 10).
\end{abstract}

Keywords: intellectual property rights, property, possessions, European Convention on Human Rights

\section{Introduction}

European Convention on Human Rights (hereinafter referred to as "Convention") covers rather wide range of fundamental rights. However, under conditions of evolutive (dynamic) commentation of Convention provided by European Court of Human Rights (hereinafter referred to as "ECHR") the rights guaranteed by Convention get new interpretation that gives backgrounds for making conclusion that Convention was added with "new rights".

When analyzing the phenomenon of "new rights" Kovler A.I. (Kovler A.I., 2015) writes that some scientists assess concepts of many fundamental rights and mechanism of their implementation with a large dose of skepticism and stand for significant renewal of both of them (Campbell et al., 2003), second ones wonder if fundamental human rights will survive upon conditions of XXI century's challenges (Gearty C., 2005), and another scientists demonstrate keen interest to revealing influence of world's religions, national cultures on human rights (Ringelheim J., 2006, Foblets M.C., 2010). We should also put emphasis on the fact that on the faculty of right in Leon university named after Moulen J. the entire team of researchers work on the problematics of "new human rights" (Doumbé-Billé S., 2012).

In addition for the purposes of the present article it is necessary to specify that ECHR, as it is known, has worked out the autonomic concept of "possessions" that significantly differs from the understanding of property and property right in national right of states being participants of Convention.

The main provision that has become basis for the whole decisional law in regard of "possessions" in terms of article 1 of Protocol No. 1 to convention was formulated by ECHR in 1995 within the framework of Gasus Dosier- und Fördertechnik $\mathrm{GmbH}$ v. the Netherlands case. In the decree on this case it was noted that the term of "possessions" used in article 1 of Protocol No 1 has autonomic meaning, which is definitely not limited with the right of property in respect of 
physical objects. To the term of "possessions" used in article 1 of Protocol No. 1 to Convention, in Court's opinion, not only things in their tradition understanding can be referred, but also some other rights and interests forming assets that can be considered property rights and, consequently, the "possessions".

In particular, in the case of Smith Kline and French Laboratories Ltd. v. the Netherlands it was said that the term of "possessions" fixed in article 1 of Protocol No. 1 to Convention covers patents (that affirm the sole rights of patent owner to invention, useful model, etc.), while the patent owner in his turn was referred to the category of property owner (within the framework of which the rights of intellectual rights are considered).

The claim about wide understanding by ECHR of "possessions" term is also highlighted in case, of Paeffgen GMBH v. Germany, in the framework of which Court envisaged the matter of eligibility for registration of domain name being affined to the trademark of other legal person. As a result of the case Court admitted the right to domain name is a "possessions" in terms of article 1 of Protocol No. 1 to Convention and is provided by provisions of the present article (Benedek and Kettemann, 2012). It is obvious that named property right is not covered by the term of "property right", as well as it is not being intellectual right (WIPO document WIPO/INT/02)), however it is the economical value of this right that allows referring it to "possessions" in terms of article 1 of Protocol No. 1 to Convention.

Another example of wide interpretation by ECHR of "possessions" term is the SC Editura Orizanturi SRL v. Romania case, in the decree on which ECHR had admitted that provisions of article 1 of Protocol No. 1 to Convention cover right to publication - the right that far not in all the national legislation is recognized as property right.

In Europe thank's to large part to activities of ECHR there is change of position in respect of what can be referred to property. Thus, in FRG and Holland there was evolution of understanding of property to its wider interpretation (Mincke, 1997). The concept of wide understanding of property formulated by ECHR had definite impact on Russian law (Rozhkova M.A., 2007; Afanasyev D.V., 2012).

In the modern world the significance of such property as intellectual property rights is constantly increasing. As a result there is nothing extraordinary in the fact that intellectual property is expressly mentioned as possessions in article 17 (2) of the Charter of Fundamental Rights of the European Union named "Right to property" (Commentary of the Charter of Fundamental Rights of the European Union, 2006). In that connection in the Strategy on the effective implementation of the European Charter of Fundamental Rights (COM (2010) 573 final) there is an emphasis on the necessity of solving questions of intellectual property.

Along with this not always the results of creative self-expression can get legal protection and defense as "possessions" of interested person: such a legal protection can be not performed, for example, in case if in accordance with national legislation such results are not referred to the objects of intellectual property. Can one protect intellectual property that had not got legal protection in accordance with national legislation? What mechanisms of Convention can be used for defense of creativity results in situations, when the autonomic concept of property developed by ECHR can not be applied.

\section{Intellectual Property as the "Available Property"}

We would like to start the consideration of named matters with specification of that "possessions" by the meaning attached to it in decisional practice of ECHR is subdivided into two general categories. The first category covers "existing possessions"; the second one is the "legally expected assets" including requirements, in regard of which claimer can prove that he possesses at least legitimate expectation for realization of his property right.

The term of "existing possessions» is undoubtedly understood by ECHR as not only physical objects being in the possession of right holder - the present category includes not only things, but also lien, the term on which has accrued, and also, beyond all question, intellectual property.

The term of "existing possessions" implies that claimer has legal title in respect of particular property, i.e. according to national legislation the claimer is considered legal holder (owner, right holder) of the property in all its legal aspects. In Anheuser-Busch Inc. v. Portugal case Great Chamber had underlined that in every case, in which article 1 of Protocol No. 1 to Convention is appealed it is necessary to set if the claimer in corresponding circumstances taken into account in the aggregate possesses courtesy title for property right, the violation of which is being appealed by him (see also: Beyeler $\mathrm{v}$. Italy (GC); Broniowski v. Poland (GC)).

On the assumption of above-said intellectual property will be recognized as "existing property", if interested person can afford proofs of belonging to him of corresponding rights, can consolidate the possession of intellectual property rights with help of patent for an invention (or useful model), certificate of authorship on selection achievement, due to availability of the record about commercial designation in local register, etc.

Except for specified issues the legal basis in respect of "existing property" can be proved by, for example, 
adjudications of national courts.

Thus, in the case of Plodovaya Kompaniya v. Russia corporate applicant approved of being in her possession of exclusive rights to trademark in regard of alcohol production referring to the fact that it is being universal legal successor of company that earlier possessed exclusive rights to the present trademark (of right holder company). In the mean time the case related to succession of corporate applicant had been considering by national courts and the end to it was put by the Presidium of Supreme Arbitration Court of the Russian Federation (the highest judiciary instance of commercial courts that was in force for that moment). By disaffirming the decree of judiciary instance and remaining in effect the decision of court of original jurisdiction, the Presidium of SAC of RF admitted that corporate applicant had no right to recognize itself as legal successor of right holder company, as far as the decision of reorganization had not been adopted and the corporate applicant was established as a new legal body rather than appeared as a result of right holder company transformation.

ECHR noted that in national courts there was a dispute in respect of corporate applicant's availability of universal succession, on the result of which its right to trademark was depended, however national law courts had not confirmed availability of succession, i.e. judicial act that could certify the right of company to trademark was not accepted. With consideration of this fact ECHR specified that under conditions of the dispute in respect of the present trademark and absence of judicial decision, by means of which national court would confirm the right of company to the trademark, in terms of article 1 of Protocol No. 1 to Convention the claimer does not possess disputed property.

The specified case contains negative conclusion of ECHR in regard of recognizing corporate applicant's intellectual property rights. However developing the quoted position of ECHR we can conclude that in the situation when intellectual property right, in respect of which there was a dispute, was recognized by judicial decision of national court (and the decision is final), there are all the background for speaking about "existing possessions", even if it had not been drawn in corresponding registration bodies. Other would contradict generally binding force of juridical decision. Such a situation can occur, for example, under conditions, when specific person was entitled by national court of having exclusive right to trademark, and although the person recognized by right holder yet is not in possession of proper protection document, recognition of the right by court makes the person a right holder and allows considering right to trademark "existing possessions".

\section{Intellectual Property as "Legally Expected Assets"}

The term of "legally expected assets" means justified supposition about having some pecuniary interest or getting pecuniary asset on the assumption, in particular, agreement concluded by government authority boy and issued by public body of authorization or license, regulatory or substandard act.

The "legally expected assets" should be understood as claimer's availability of foundations for considering his property right will be afterwards realized. As many times it was specified by the Great Chamber of ECHR "legal expectation" is the right of claim, in respect of which a person can soundly take up the position that it possesses at least justified expectation of reaching effective realization of property right (see: Pye (Oxford) Ltd and J.A. Pye (Oxford) Land Ltd v. the United Kingdom (GC); Maltzan and others v. Germany (GC)).

As it was mentioned above, the foundation for "legal expectation" can be the standards of national legislation presenting property rights or profits to private person. In the situation when the standards of applicable legislation or the legislation that was in force earlier are canceled or recognized as retrospective one can raise a point about violation of "legal expectation" guaranteed by article 1 of Protocol No. 1 to Convention and the government should bear responsibility for actions of its bodies, as a result of which the expectations of private persons for getting some property benefit were disappointed. And it doesn't matter if a person loses its rights to claim in respect of government or in respect of other private persons (Lecarpentier and other v. France).

The foundation for "legal expectation" can also be a judicial decision that sustains eligibility for interested person's right of claim. In such cases the demand of paying funds or another demand emerged on the assumption of judicial decision can be recognized as property in terms of article 1 of Protocol No. 1 only under the condition that they subject to obligatory performance (Burdov v. Russia). This supposes that judicial decision, on the basis of which the present demand had emerged, meets the following requirements:

- $\quad$ firstly, the judicial decision is being final;

- secondly, the decision contains all the information necessary for its performance: it should be sufficiently clear and specific to be enforceable;

- thirdly, on the assumption of the present decision the execution of legal process was initiated.

The peculiarity of "legal expectation" is that it can also be based on the legal foundation that had been existing 
earlier, but later was recognized by national court as invalid. In such circumstances ECHR can admit availability of "legal expectation" (existing of expected assets) even in the situation when national courts had decided that claimer does not possess the rights (title) to property - such a position was reflected in the case of Pine Valley Developments Ltd. and Others v. Ireland, in which ECHR for the first time used the term of "legal expectation". Thus, ECHR can provide protection for "legally expected asset" under conditions when in accordance with national legislation the claimer had lost his title to property (property rights).

As antipode for "legal expectation" ECHR uses "hope of recognition of a property right" category. The "hope of recognition of a property right" is not recognized as "property" in terms of article 1 of Protocol No. 1: thus, expectation for getting inheritance (hope for getting inheritance) is traditionally not considered "property" (Marckx v Belgium). The delimitation of "legal expectation" and "hope of recognition of a property right" concepts represents a severe problem in practice that had been reviewed by ECHR for many times.

The term of "hope of recognition of a property right" covers the rights, factual realization of which is impossible due to the reasons that do not depend on claimer.

In particular, the "hope of recognition of a property right" is the demand that is not subject to obligatory realization (see: Polacek and Polackova v. the Czech Republic (GC)). Thus, if "legal expectation" is represented as the demand (right) that was admitted by specific statuary provision or specific judicial act, as the consequence of which should be performed in obligatory manner, the "hope of recognition of a property right" is only a legal possibility that is not being justified and determined enough to be performed in obligatory manner.

As it was mentioned, the reasons, due to which the "hope of recognition of a property right" can not be realized, do not usually depend on claimer: it can be the actions of third parties or the absence in national legislation of norms that would provide possibility for claimer's rights realization. In this connection the Great Chamber of ECHR formulated the following provision: the "hope of recognition of a property right" is represented with contingent claim that can not be realized, if any condition that doesn't depend of right holder's will was not performed (Prince Hans-Adam II of Liechtenstein v. Germany (GC). In addition, the Great Chamber specified that only hope for restoration of ceased right or the right of claim subject to some provision that had been terminated in consequence of the condition, can not be referred to property right (Gratzinger and Gratzingerova v. the Czech Republic (GC).

For the purposes of the present work the case of special interest is the Anheuser-Busch Inc. v. Portugal case that is being quite significant due to the consideration within its framework of matters related to both - the sphere of intellectual property and the relimitation of terms "legal expectation" and "hope of recognition of a property right". We should note that when resolving the case ECHR had explicitly analyzed the provisions of Paris convention on defense of industrial property, the Madrid agreement on international registration of mark, the Madrid Protocol to it and also Agreement about trade aspects of intellectual property (TRIPS) and the Regulation of EU council about trademark (1993).

In the present case corporate applicant being a producer of beer appealed in ECHR violation of article 1 of Protocol No. 1. When justifying its position, the corporate applicant referred to recognition of invalid registration of "Budweiser" trademark in respect of the beer produced by it, the foundation for which was the antecedent international registration of "Budweiser" designation by Czech company as the name of the place of production of the good.

At the initial phase of consideration of the case the Chamber of ECHR noted that intellectual property falls under the category of "property" in terms of article 1 of Protocol No. 1 to Convention. However, submission of the application for registration of trademark (though it reflects financial interest of claimer) not yet involve emergence of "property", as far as provisions of article 1 of Protocol No. 1 to Convention cover the property that is being in the possession of person. Court had highlighted that in considered case the corporate applicant could not be sure that it is being a right holder till the moment of the end of trademark registration and only under the condition that neither third party will object against such registration. In other words, the corporate applicant had a right that was subject to definite provision (the absence of third parties' objections) and in connection with performance of the provision (receipt of objections of third parties referred to violation of their exclusive rights for registration of the trademark) the present right of corporate applicant had ceased. As a consequence of this the Chamber made the following conclusion: the right to trademark is being "property" in terms of provisions of article 1 of Protocol No. 1 to Convention, however it becomes "property" only after its final registration in accordance with the norm of national legislation; prior to such registration the person submissioned application has only "hope for getting right" (but not "legal expectation" that is subject to legal defense). With account of this it was concluded that the corporate applicant did not possessed the right to "property" in terms of article 1 of Protocol No. 1 to Convention.

The present case was reconsidered by the Great Chamber of ECHR and the initially formulated position was changed.

In the decree of the Great Chamber it was noted that the bodies that were created on the basis of Convention, very seldom have to resolve questions linked to protection of intellectual property. For the purpose of considering the case in 
the decree there was overview of cases related to acquisition of rights to objects of intellectual property. In particular, it was specified that in earlier mentioned case of Smith Kline and French Laboratories Ltd. v. the Netherlands there was reference that "property" term fixed in article 1 of Protocol No. 1 to Convention covers patents. In the decree on British American Tobacco Ltd v. the Netherlands case there was an opinion, according to which article 1 of Protocol No. 1 can not be applied to application for patent that was deflected by competent authority body, and that is why the corporate applicant, registration of patent of which was deflected, does not obtain the right to "property", and the refusal in registration does not mean loss of the right to property. In the case of Hiro Balani v. Spain the question of permissibility of applying article 1 of Protocol No. 1 to Convention to objects of intellectual property had not been considered, however Court recognized as violation of point 1 of article 6 of Convention ("The right to a fair trial") the fact that Supreme court of Spain had not considered non-compliance of priority rules as foundation for appeal of judicial decision.

When analyzing the question of applying of provisions of article 1 of Protocol No. 1 to Convention in the case of Anheuser-Busch Inc. v. Portugal the Great Chamber agreed that registration of trademark (and correspondingly - legal protection of intellectual property issued due to such registration) becomes final only in the case, if such registration does not violate legal rights of third parties. Thereby it was admitted that rights linked to submission of application are subject to definite condition. However, in opinion of ECHR, corporate applicant had a right to expect for its consideration in accordance with standards of applicable legislation (if they satisfy all the substantive and procedural requirements), and that is why there are foundations for making conclusion that corporate applicant disclosed interests of property nature that fall under action of article 1 of Protocol No. 1 to Convention/ In its decree the Great Chamber highlighted that submission of application causes a big number of financial rights and interests (for example, signing of license agreement with payment of remuneration, wage assignment of application for registration of trademark, etc.). As the consequence of above-said we made a conclusion that the corporate applicant had possessed "a number of property rights" linked to its application for registration of trademark, i.e. it was admitted that having made application for registration the corporate applicant acquired the right for "possessions" in terms of article 1 of Protocol No. 1 to Convention. As far as such rights should be referred to "existing possessions", the Great Chamber of ECHR specified that there is no necessity of considering question of whether corporate applicant can pretend to "legal expectation".

When putting over the analysis of Anheuser-Busch Inc. v. Portugal case we would like to highlight the fact that by admittance of corporate applicant's property rights ECHR does not mention that the point is about exclusive rights for trademark (the intellectual property rights). This means that in the decree on considered case Court, in fact, confirmed earlier formulated position, in accordance with which submission of application (for getting patent, for registration of trademark) does not mean acquisition of intellectual property, but admits recognition of claimer's other property rights and interests that fall under term of "property".

\section{Divulgation of Intellectual Activity Results as Realization of Right to Express Opinion}

In some cases it is obvious that limitation of opportunity of realizing intellectual property rights can not be overcome with help of article 1 of Protocol No. 1 to Convention. In such cases it is necessary to address to other provisions of Convention.

Thus, not the matter of property, but the matter of other conventional rights was considered at trial of Ahmet Yildirim v. Turkey case. In the framework of the case ECHR ascertained that the claimer is being an owner of informational resource (designed with help of Google Sites (<sites.google.com>) service), where he published his scientific works and materials that reflect his view on various questions. In June of 2009 national court in the framework of struggle against crimes in Internet made a decision about application of initial measure in form of blocking of site being in the possession of other owner (hereinafter referred to as "site of violator"), but then the decision was changed to blocking of access to all the sites designed by means of Google Sites. As the consequence of this the claimer was deprived of access to own site and, consequently, restricted in possibility of making the public aware of his view and results of scientific activity. Petition about cancellation of the decree in respect of claimer's site was denied by national court and as at April, 2012 claimer as before can not use his site, despite the fact that criminal case in respect of owner of other site (site of violator with illegal content) was ceased in March, 2011.

ECHR recognized such blocking as limitation of claimer's right to freedom to express opinions (article 10 of European Convention on Human Rights). It was explained with the state that Google Sites service was designed for facilitation of creation and joint use of sites in Internet, due to which it is being a mean of realization of freedom of word. Besides, European Court had referred the fact that blocking of access to all the sites on Google Sites is the limitation of Internet users' right to get information, as far as the Internet nowadays has become one of the main means, with help of which people realize the right to express opinion, and also to getting and distribution of information guaranteed by article 
10 of Convention. Meanwhile, in the decree of Court it was noted that Google Sites contains such significant quantity of data and information in its volume comparable to online-archives of major newspapers or traditional libraries. At the same time national court on account of one mere violator made a decision about blocking access to all the resources of Google Sites and very big volume of information for indefinite time.

In its decree on case of Ahmet Yildirim v. Turkey ECHR noted that when making decision about blocking Google Sites as initial measure, national court acted on the assumption of the fact that it is the only way of blocking violator's site. In the meantime, such measure in the present case can not be considered the only possible way - blocking access to all the resources of Google Sites on account of one mere violator is the limitation of freedoms guaranteed by article 10 of Convention.

We cannot but recognize that matters of intellectual property and also realization of rights in the Internet, although they are considered by European Court, by its admittance, rather seldom explicitly examined due to their major significance and relevance. In this connection there is no wonder in the fact that many cases, which to this or that decree touch the analyzed problematics, are delivered to the Great Chamber, the competence of which implies consideration of serious questions affecting interpretation or application of Convention and Protocols to it. Thus, recently (on February 17, 2014) the case of Delfi AS v. Estonia, in the framework of which, in particular, the question of responsibility of informational mediators had been resolving, was delivered to consideration of the Great Chamber.

\section{Conclusions}

Making conclusions we should admit that insignificance of number of cases, in which ECHR had been considering the matters of intellectual property, undoubtedly, does not allow resolving many questions emerged in the sphere of legal protection and defense of rights for results of intellectual activity and different designations. Alongside with that use of conclusions made by ECHR in interpreting different provisions of Convention, including - in the cases, in which the sphere of intellectual property is not affected, quite often gives rich food for further developments in the considered sphere presenting answers to quite practical questions. For example, analysis of decisional practice of ECHR allows making conclusion that in the situation when the result of private person's creativity can not get legal protection in accordance with national legislation, the rights to such result can be recognized as "possessions" in terms of article 1 of Protocol No. 1 to Convention and get defense in this very aspect. In similar way the property interests of person submissioned application for getting patent are considered: ECHR admits the person's property right, although does not recognize it as intellectual property. However even in the cases when person can not protect his right to creative selfexpression by means of using provisions of article 1 of Protocol No. 1 to Convention, the decisional practice of ECHR provides other instruments for persons' defense, whose rights were violated.

For the purpose of development of above said we would like to put an emphasis on the following matter. Analysis of interrelations between human rights and modes of intellectual property allowed forming of different expert's positions, which were suggested to incorporate into three groups (Helfer and Laurence, 2011). Scientists of the first group pay attention to historical roots of emergence of two systems - the human rights system and system of intellectual property, trying to mitigate tension caused by intersection of the systems (Torremans, 2004; Yu, 2007; Shaver and Sganga, 2009). The second group of scientists address to relation of intellectual property with human rights for the purpose of providing possibility of reconsidering imperfect mechanisms that exist in national legislations about intellectual property on the assumption of urge to defense rights of the persons not being right holders - the consumers, potential right holder and the entire community (Srowel and Tulkens, 2005; Hugenholtz and Okediji, 2008). Experts of the third group try to use the system of human rights for creation of maximal protection of intellectual property and refer to fundamental rights (Geiger, 2006; Raustiala, 2007).

The problem of interrelation between international system of human rights and national systems of intellectual property is also being noteworthy. In the framework of the paper it appears that there are foundations for making conclusion that ECHR demonstrates its position in respect to the present problem. When resolving the question of intellectual property protection on the assumption of Convention's goal - to protect rights and freedoms of man - tends to present real protection for the rights that were violated and does not determine at the same time the priority subject of protection.

\section{Acknowledgement}

The work was conducted with financial support from Ministry of Education and Science of the Russian Federation at the expense of national task for performing scientific and research work under project 1865. 


\section{References}

Afanasyev, D. V. (2012). Filing of a complaint in European Court of Human Rights ("Practice of European Court of Human Rights: comment judicial precedents" series, book 1). Moscow: Statut. pp. 263-284

Yildirim, A. (2012). Turkey, 18.12.2012, no 3111/10

Anheuser-Busch Inc. (2007). Portugal (GC), 11.01.2007, no 73049/01

Benedek, W., Kettemann, M. S. (2012). Freedom of expression and the Internet. Council of Europe, Strasbourg 2012, p. 96

Beyeler (2000). Italy (GC), 05.01.2000 no 33202/96;

British American Tobacco Ltd (1995). The Netherlands, 20.11.1995, no 19589/92

Broniowski (2004). Poland (GC), 22.07.2004 no 31443/96

Campbell, T., Ewing, K.D., \& Tomkins A. (Eds.) (2003). Sceptical Essays on Human Rights. Oxford.

Commentary of the Charter of Fundamental Rights of the European Union (June 2006). pp. 163-169. Retrieved from: http://ec.europa. eu/justice/fundamental-rights/files/networkcommentaryfinal_en.pdf

Delfi. A. S. (2013). Estonia, 10.10.2013, no 64569/09

Doumbé-Billé, S. (dir.). (2012). Nouveaux droits de l'homme et internationalisation du droit. Bruxelles.

Foblets, M.-C.e.u. (Ed.). (2010). Cultural diversity and the law. Brussels.

Gasus Dosier- und Fördertechnik GmbH (1995). The Netherlands, 23.02.1995, no 15375/89

Gearty, C. (2005). Can Human Rights Survive? Cambridge.

Geiger, Ch. (2006). "Constitutionalising" intellectual property law? The Influence of fundamental rights on intellectual property in the European Union. 37 Int 'I Rev. Intell. Prop. \& Competition L. 371.

Gratzinger, \& Gratzingerova (1994). The Czech Republic (GC), 10.07.2002, no 39794/98

Balani, H. (1994). Spain, 09.12.1994, no 18064/91

Hugenholtz, B. \& Ruth L. (March, 2008). Okediji, conceiving an international instrument on limitations and exceptions to copyright: Final report.

Intellectual Property on the Internet: a Survey of Issues (2002). WIPO document WIPO/INT/02. Geneva. Retrieved from: http://www. wipo.int/edocs/pubdocs/en/intproperty/856/wipo_pub_856.pdf)

Pye, J.A. (2007). Ltd and J.A. Pye (Oxford) Land Ltd. The United Kingdom (GC), 30.08.2007, no 44302/02

Kovler A. (2015). From the chairman of editorial team of the yearbook (in lieu of a preface). Russian Yearbook of the European Convention on Human Rights, 1(2015). Moscow, p. 13

Helfer, L. R., \& Austin, G. W. (2011). Human rights and intellectual property: Mapping the global interface. Cambridge University Press.

Lecarpentier et al. France, 20.02.2006, no 67847/01

Maltzan and others (2005). Germany (GC), 02.03.2005, nos 71916/01, 71917/01 and 10260/02

Marckx (1979). Belgium .

Mincke, W. (1997). Property: Assets or power? Objects or relations as substrata of property rights. Property problems: from Genes to Pension Funds. In Harris J.W. (Ed). Kluwer Law International, pp. 78-80

Paeffgen GMBH (2007). Germany, 18.09.2007, nos 25379/04, 21688/05, 21722/05 and 21770/5

Torremans, P. L. C. (Ed.). (2004). Copyright and Human Rights: Freedom of Expression - Intellectual Property - Privacy 1.

Pine Valley Developments Ltd. et al. (1991). Ireland 29.11.1991, no 12742/87

Plodovaya Kompaniya (2007). Russia, 07.06.2007, no 1641/02

Polacek and Polackova (2002). The Czech Republic (GC), 10.07.2002, no 38645/97

Prince Hans-Adam II of Liechtenstein (2001). Germany (GC), 12.07.2001, no 42527/98

Raustiala, K. (2007). Density and conflict in international intellectual property law, 40 U.C. Davis L. Rev. 1021, 1032.

Ringelheim, J. (2006). Diversité culturelle et droits de l'homme. Bruxelles.

Rozhkova, M. A. (2007). The notion of "property" in the legal provisions of European Court of Human Rights. Civic transactions objects: collected works. In Rozhkova, M.A (Ed.). Moscow: Statut, pp. 95-112

SC Editura Orizanturi SRL (2008). Romania, 13.05.2008, no 15872/03

Shaver L., \& Sganga, C. (2009). The right to take part in cultural life: on copyright and human rights, 27 Wisc. Int'I L. Rev. 637

Smith Kline and French Laboratories Ltd. (1990). The Netherlands, 04.10.1990, no 12633/87

Strategy for the effective implementation of the Charter of Fundamental Rights by the European Union (2010). Brussels, 19.10.2010. COM (2010) 573 final Retrieved from: http://eur-lex.europa.eu/LexUriServ/LexUriServ.do?uri=COM:2010:0573:FIN:en:PDF

Strowel A., \& Tulkens F. (2005). Freedom of expression and copyright under civil law: of balance, adaptation, and access. In J. Griffiths \& U. Suthersanen (Eds.). Copyright and Free Speech, Comparative and International Analyses

Peter K. Yu. (2007). Reconceptualizing intellectual property interests in a human rights framework, 40 U.C. Davis L. Rev. 1039 
ISSN 2039-2117 (online) ISSN 2039-9340 (print)
Mediterranean Journal of Social Sciences MCSER Publishing, Rome-Italy
Vol 6 No $3 \mathrm{~S} 3$ May 2015 